\title{
Abundance of post-larval Callinectes sapidus, Penaeus spp., Uca spp., and Libinia spp. collected at an outer coastal site and their cross-shelf transport
}

\author{
Alan L. Shanks* \\ Oregon Institute of Marine Biology, University of Oregon, PO Box 5389, Charleston, Oregon 97420, USA
}

\begin{abstract}
The abundance of the megalopae of Callinectes sapidus, Uca spp., and Libinia spp. and the post-larvae of Penaeus spp. settling on collectors hung from the end of the Army Corps of Engineers' Field Research Facility (FRF) pier in Duck, North Carolina, USA, was measured daily during the period 2 August through 3 November 1994. During this period the coastal oceanography was dominated by the effects of the winds; winds from the NE tended to generate surface onshore flow and downwelling while those from the SW tended to generate surface offshore flow and upwelling. If the post-larvae were transported shoreward by coastal currents then variations in their abundance should relate to the physical parameters which generate the transporting currents. Using time-series analysis the daily abundance of post-larvae was statistically analyzed and compared to along- and cross-shore wind stress, along- and cross-shore current speed near the bottom $(23 \mathrm{~m})$ and near the surface $(4 \mathrm{~m})$, and temperature, salinity, and current speed measured at the end of the FRF pier. Fourier analysis suggested that the abundance of post-larval C. sapidus and Penaeus spp. varied on a semi-lunar cycle, e.g. $15 \mathrm{~d}$. No cycles were apparent in the Fourier analysis of the abundance of Uca spp. megalopae and the megalopae of Libinia spp. varied on an 18 d cycle. Significant cross-correlations were found between the log-transformed daily abundance of post-larval $C$. sapidus and Penaeus spp. and the maximum daily tidal range, which, coupled with the Fourier analysis, suggests that peak catches of these postlarvae tended to occur at and just after the spring tides. The cross-correlation analysis suggests that abundance of $U c a$ spp. megalopae was weakly related to the tides, with peak catches tending to occur around the spring tides. No significant cross-correlations were found between the abundance of Libinia spp. megalopae and the maximum daily tidal range. To test for the effects of the other physical variables on post-larval abundance Autoregressive Integrated Moving Average (ARIMA) models were fitted to the biological and physical data, and cross-correlations were run between the residuals from these models. The analysis suggests that the abundance of $C$. sapidus megalopae did not vary with any of the measured physical variables, Penaeus spp. and U/ca spp. tended to be more abundant during periods of onshore surface flow and downwelling. while Libina spp. megalopae tended to be more abundant during periods of offshore surface flow and upwelling. The results of this study suggest that post-larval C. sapidus and Penaeus spp. were transported shoreward by tidally driven processes, both Penaeus spp. and Uca spp. were transported shoreward by wind-driven surface currents, and Libinia spp. megalopae were transported shoreward in near-bottom waters during upwelling events.
\end{abstract}

KEY WORDS: Megalopae - Post-larvae - Dispersal - Transport - Callinectes - Uca Libinia Penaeus Recruitment Settlement

\section{INTRODUCTION}

Many intertidal and estuarine invertebrates and fish produce planktonic larvae which go through their larval development in the waters over the continental shelf. Larval development times can be as short as days, but are more typically on the order of several

•E-mail:ashanks@oimb.uoregon.edu weeks to months. During their residence in the plankton, larvae can be transported tens to hundreds of kilometers offshore. At the end of this planktonic period the larvae must migrate (sensu Kennedy 1961) from their location in the plankton back to the habitat into which they will settle.

The return migration of most intertidal or estuarine invertebrates to the coastline is probably due to transport in shoreward directed currents. A variety of shore- 
ward transport mechanisms have been suggested (reviewed in Shanks 1995), including wind-driven currents, shoreward propagating convergences associated with tidally driven internal waves or the relaxation of a wind-or tidally generated upwelling front, transport within shoreward propagating tidally generated internal bores, and currents generated by the density structure over the continental shelf. The dominant shoreward transport mechanism for a species will be dependent on the behavior of the larvae and the local oceanography. Variations in a time-series of settlement or abundance of the migrating larval stage should be significantly related to the physical variables which are causing their shoreward transport.

Using this time-series approach the return migration of megalopae of the blue crab Callinectes sapidus has been extensively studied along the Atlantic and Gulf of Mexico coasts of North America (Rabalais et al. 1995, van Montfrans et al. 1995, Morgan et al. 1996). Timeseries of the daily abundance of megalopae have been made by deploying collectors which exploit the high thigmokinesis of the megalopae (Metcalf et al. 1995). The collectors, which generally consist of a mesh cylinder, are hung in the water; megalopae encountering the trap cling to it, and, when the trap is retrieved, the megalopae are washed off into a bucket. This technique provides a simple, inexpensive and reliable (Metcalf et al. 1995) means of estimating the relative abundance of megalopae.

All of these time-series of blue crab megalopal abundance have been made within estuaries (Rabalais et al. 1995, van Montfrans et al. 1995, Morgan et al. 1996). These studies have found that the abundance of blue crab megalopae varies greatly from day to day, with a tendency for peak catches to occur on a fortnightly lunar cycle and/or when the winds generate shoreward surface flow. Megalopae caught within an estuary have been transported across the continental shelf and then have entered and migrated up an estuary (Boehlert \& Mundy 1988). Hence, the fluctuations in their abundance may be due to at least 2 processes transport to the coast and ingress into the estuary. These time-series cannot be used to unambiguously investigate the mechanism(s) of cross-shelf migration of blue crab megalopae.

The mechanism(s) of onshore transport for a species is dependent on the depth at which they reside. Callinectes sapidus megalopae inhabit the neuston (Smyth 1980. Johnson 1985); hence, their transport mechanisms must be ocean surface phenomena. In contrast, post-larval Penaeus spp. vertically migrate between the near surface waters and depths (e.g. $>10 \mathrm{~m}$ ) within the water column (Temple \& Fischer 1965), and Uca spp. megalopae have been collected in deeper plankton tows (Johnson 1985) as well as near the surface
(Dudley \& Judy 1971). Phenomena responsible for the onshore transport of the post-larvae of Penaeus spp. and $U c a$ spp. may not be the same as those responsible for the shoreward transport of $C$. sapidus megalopae.

In this paper I present the results of a study of the abundance of 4 species (Callinectes sapidus, Penaeus spp., $U_{C a}$ spp., and Libinia spp.) caught on collectors deployed outside of an estuary. Using time-series analysis, the daily abundance of post-larvae was statistically compared to physical variables which might generate onshore transport.

\section{METHODS}

Samples were collected between 2 August and 3 November 1994 from the pier at the Army Corps of Engineers' Field Research Facility (FRF), Duck, North Carolina, USA $\left(36^{\circ} 10^{\prime} 54.6^{\prime \prime} \mathrm{N}, 75^{\circ} 45^{\prime} 5.2^{\prime \prime} \mathrm{W}\right)$ and from the Atlantic Ocean adjacent to the FRF pier (Fig. 1). The pier at FRF is located along the Outer Banks approximately $40 \mathrm{~km}$ north of Oregon Inlet which is connected to Currituck Sound and approximately $100 \mathrm{~km}$ south of the mouth of the Chesapeake Bay. The shoreline around the pier is sandy beach which extends for tens of $\mathrm{k} . \mathrm{m}$ up and down the coast. The maximum tide range is around $1 \mathrm{~m}$.

The FRF pier extends $403 \mathrm{~m}$ out to sea (Birkemeier et al. 1981). The pier pilings are $12.2 \mathrm{~m}$ apart. Cylindrical mesh collectors similar to those used to sample megalopae in a number of previous studies (e.g. Metcalf et al. 1995) were hung at a distance of $385 \mathrm{~m}$ from shore. The collectors were cylinders $10 \mathrm{~cm}$ in diameter and 41 $\mathrm{cm}$ long composed of $2 \mathrm{~cm}$ thick Enkamat ${ }^{\oplus}$. Enkamat ${ }^{\oplus}$ is a matrix of semi-rigid nylon monofilaments fused at their intersections which is used in aquaculture as an egg-laying mat for fish. Two collectors were fished. One was buoyant and rose and fell with the tide. The second was positioned approximately $1 \mathrm{~m}$ off the bottom at a depth of $5.6 \mathrm{~m}$ below mean low water. The col. lectors were hung midway between the second and third pair of pier pilings from the seaward end of the pier. In this position the collectors were $6.4 \mathrm{~m}$ from any pilings.

The collectors were removed once a day and vigorously shaken in separate buckets of seawater. Repeated washing of collectors demonstrated that nearly all of the attached organisms were removed by one washing. The contents of the buckets were poured through $53 \mu \mathrm{m}$ mesh screens and the retained material taken to the laboratory for counting. The entire contents of each collector was enumerated under a dissecting microscope and megalopae were identified using standard sources (Hyman 1920, Costlow \& Bookhout 1959, Cook 1966, Sandifer \& Van Engel 


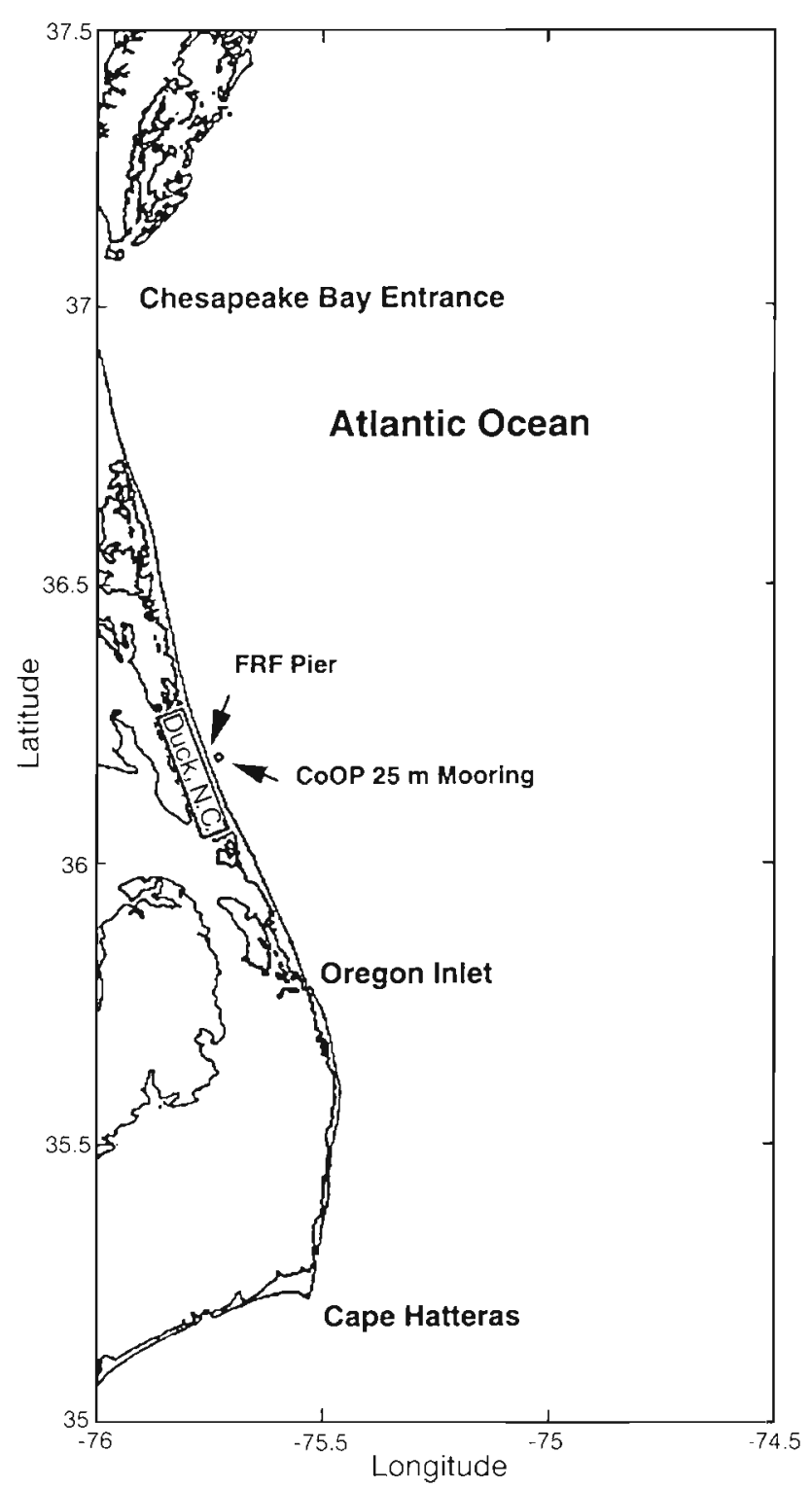

Fig. 1. Location of the Army Corps of Engineers' Field Research Facility (FRF) pier, Duck, NC, USA, where the timeseries of daily abundance of post-larval crabs and shrimp was measured. Temperature, salinity, wind speed and direction, and current speed were also measured at the pier by the Army Corps of Engineers. The locations of the CoOP oceanographic mooring and the FRF pier are indicated

1971, Johns \& Lang 1977). Samples were preserved in $5 \%$ buffered formalin.

Physical data were collected at FRF and at instrumented moorings deployed by CoOP (Coastal Ocean Processes) study participants. Wind speed and direction were measured at a weather station located at FRF. FRF also provided predicted tidal range and current speed data from the end of the FRF pier. Temperature and salinity measurements were made with Seabird Seacat ${ }^{(1)}$ CTDs (conductivity-temperature- depth profilers) mounted on the pier pilings of the FRF pier. Measurements were made every 4 min throughout the sample period. Measurements of temperature, salinity, and current speed and direction were also collected by instruments on a mooring which was set at approximately $16 \mathrm{~km}$ offshore at a depth of $25 \mathrm{~m}$. Temperature and salinity were measured by CTDs while current speed and direction were measured with vector-measuring current meters (VMCM). Measurements began on 7 August and were made every 4 min throughout the sample period. More detailed descriptions of the sampling at FRF and the offshore moorings can be found in Birkemeier et al. (1981) and Alessi et al. (1996), respectively.

The wind data were used to compute along- and cross-shore wind stress using standard equations (Pedlosky 1987). Currents were also broken into their along- and cross-shore components. Data were averaged over each day. The maximum daily tidal range was defined as the maximum change in tidal elevation between a high and adjacent low tide during a $24 \mathrm{~h}$ period.

In most of the following analysis of megalopal abundance the number caught on the surface and bottom collectors were combined. Large day to day fluctuations in number were observed (see 'Results', Fig. 4). To reduce the influence of occasional large peaks in the data sets the series were $\log _{10}(x+1)$ transformed (Thorrold et al. 1994). To search for periodicity in the megalopal abundance time-series, the data were analyzed with a Fourier transfer function. In 2 of the timeseries (see 'Results') the Fourier analysis suggested that the abundances of the megalopae varied with a $15 \mathrm{~d}$ period, approximately that of the fortnightly tidal cycle. Cross-correlations were run between the maximum daily tidal range and daily abundances. Both the time-series of maximum daily tidal range and megalopal abundances displayed significant autocorrelations. The presence of these significant autocorrelations could artificially inflate the $r$ values in a cross-correlation. To account for the effects of the significant autocorrelations the corrected standard error of the crosscorrelation $\mathrm{r}$ was computed following Wing et al. (1995). This corrected standard error was used when ever it was more conservative than the white noise standard error calculated with the cross-correlation analysis.

The cross-correlations suggested that the daily abundance of some types of megalopae fluctuated with the tides. This signal was strong enough to obscure the potential effects of winds or currents on the daily abundance of megalopae. To control for the effect of tides on megalopa abundance ARIMA (autoregressive integrated moving average) models were fitted to the log-transformed megalopal abundance data. Where 
appropriate (e.g. as indicated by autocorrelations) the seasonal component of the ARIMA model was set to the time between spring tides. Models were selected following standard criteria (Jassby \& Powell 1990. Dunstan 1993). The residuals between the ARIMA model and the log-transformed megalopal abundance data were cross-correlated with residuals between ARIMAs fitted to the physical data and the values of the physical parameter.

\section{RESULTS}

\section{Physical measurements}

During the approximately 3 mo of the study, due to the influence of passing weather fronts, the winds tended to blow
Table 1. Cross-correlations between bottom and surface coastal currents and wind stress. Wind data were collected near the end of the FRF pier. Current data were collected at the $25 \mathrm{~m}$ mooring, which was $6 \mathrm{~km}$ offshore. Values are days lag followed by the cross-correlation coefficients at which significant $(p<0.05)$ cross-correlations were found

\begin{tabular}{|c|c|c|c|c|c|}
\hline & \multicolumn{3}{|c|}{ Currents } & \multicolumn{2}{|c|}{ Wind stress } \\
\hline & $\begin{array}{l}\text { Cross- } \\
\text { shore, } \\
\text { surface }\end{array}$ & $\begin{array}{l}\text { Cross- } \\
\text { shore, } \\
\text { boltom }\end{array}$ & $\begin{array}{l}\text { Along- } \\
\text { shore, } \\
\text { surface }\end{array}$ & $\begin{array}{l}\text { Along- } \\
\text { shore }\end{array}$ & $\begin{array}{l}\text { Cross- } \\
\text { shore }\end{array}$ \\
\hline \multicolumn{6}{|c|}{ Cross-shore currents } \\
\hline Surface & & & & $0: 0.343$ & $0: 0.349$ \\
\hline Bottom & $0:-0.336$ & & $0:-0.243$ & $0:-0.316$ & $0:-0.386$ \\
\hline \multicolumn{6}{|c|}{ Alongshore currents } \\
\hline Surface & $\begin{array}{l}-1: 0.242 \\
-3: 0.234\end{array}$ & & & $\begin{array}{r}0: 0.689 \\
-1: 0.706 \\
-2: 0.426\end{array}$ & $\begin{array}{r}0: 0.576 \\
-1: 0.624 \\
-2: 0.475 \\
-3: 0.369\end{array}$ \\
\hline Bottom & $0: 0250$ & $0:-0.420$ & $\begin{array}{r}0: 0.837 \\
-1: 0.508\end{array}$ & $\begin{array}{r}0: 0.721 \\
-1: 0.714 \\
-2: 0.337\end{array}$ & $\begin{array}{r}0: 0.707 \\
-1.0 .691 \\
-2: 0.439 \\
-3: 0.302\end{array}$ \\
\hline
\end{tabular}

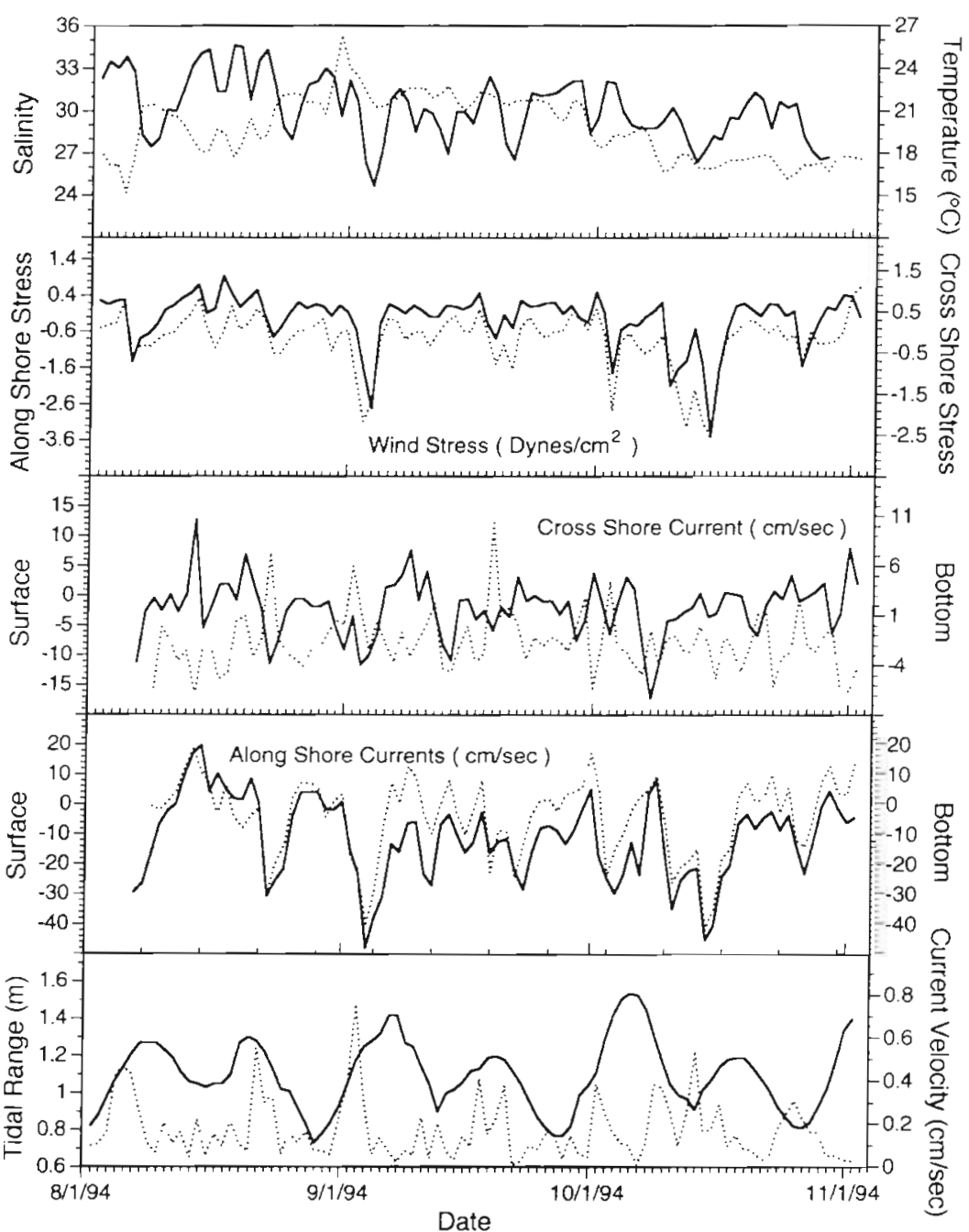

from either the northeast or the southwest (Fig. 2). These winds strongly affected the coastal currents.

The cross-shore components of the surface and bottom currents measured at the $25 \mathrm{~m}$ mooring (approximately $16 \mathrm{~km}$ offshore) were significantly positively and negatively cross-correlated, respectively, with $0 \mathrm{~d}$ lag with both the cross-shore and along-shore components of the wind (Table 1). Further, the cross-shore surface and bottom currents were significantly and negatively crosscorrelated with each other at 0 d lag (Table 1). In other words, surface currents tended to be in the direction of the wind. Bottom currents tended to flow in the opposite direction to the surface currents and the winds.

Fig. 2. Variation in the physical parameters during the period of the study $(2$ August through 3 November 1994). In each frame the values for the left hand axis are plotted as solid lines and those for the right hand axis as dashed lines. Positive and negative values of along-shore wind stress and currents represent winds or currents to the north and south, respectively. Positive and negative values of cross-shore wind stress and currents represent winds or currents flowing to the east and west, respectively. Note that current meters on the mooring were not turned on until 7 August 
Table 2. Cross-correlations between along- and cross-shore wind stress and physical variables measured at the end of the Army Corps of Engineers' Field Research Facility pier. Values are days lag followed by cross-correlation coefficients at which significant $(p<0.05)$ cross-correlations were found. ns: not significant

\begin{tabular}{|lrcrc|}
\hline $\begin{array}{l}\text { Wind } \\
\text { stress }\end{array}$ & Salinity & Temperature & $\begin{array}{c}\text { Nearshore } \\
\text { flow }\end{array}$ & $\begin{array}{c}\text { Maximum } \\
\text { daily tidal } \\
\text { range }\end{array}$ \\
\hline $\begin{array}{l}\text { Along- } \\
\text { shore }\end{array}$ & $\begin{array}{r}0: 0.454 \\
-1.0 .666\end{array}$ & ns & $\begin{array}{r}0:-0.869 \\
-1:-0.371\end{array}$ & ns \\
& $-2: 0.495$ & & & \\
Cross- & $0: 0.521$ & $0:-0.229$ & $0:-0.770$ & ns \\
shore & $-1: 0.651$ & & $-1:-0.415$ & \\
& $-2: 0.396$ & & & \\
\end{tabular}

The alongshore components of the surface and bottom currents were both positively and significantly cross-correlated with 0 to -2 or $-3 \mathrm{~d}$ lag, respectively, with the along- and cross-shore component of the wind stress (Table 1). The alongshore components of the surface and bottom currents were strongly and negatively cross-correlated with each other at 0 and -1 d lag (Table 1) and they were significantly positively crosscorrelated with the cross-shore components of the currents at the surface and bottom with -1 and -3 d lag and $0 \mathrm{~d}$ lag, respectively (Table 1). In other words, the alongshore components of the surface and bottom currents were in phase and in the direction in which the wind was blowing.

Salinity, temperature, water velocity, and tidal range measured at the end of the FRF pier were cross-correlated with the along- and cross-shore wind stress (Table 2). Surface salinity was significantly and positively cross-correlated with lags of 0 to $-2 \mathrm{~d}$ with both the along- and cross-shore wind stress (Table 2). Surface temperature was not significantly cross-correlated at any lag with the alongshore wind stress, but it was significantly and negatively cross-correlated at $0 \mathrm{~d}$ lag with the cross-shore wind stress (Table 2). Due to the proximity of the shore, flow at the end of the FRF pier was almost entirely alongshore. This flow was significantly and negatively cross-correlated with both the along- and cross-shore wind stress at lags of 0 and $-1 \mathrm{~d}$ (Table 2). There were no significant cross-correlations between the maximum daily tidal range and either component of the wind stress. Further, the maximum daily tidal range was not significantly cross-correlated with salinity, temperature, or current velocity at the end of the pier, suggesting that tidal range had little affect on these parameters. Along-and cross-shore wind stress to the south and onshore, respectively, lead to low salinity surface water and high velocity currents at the end of the FRF pier. Offshore wind stress tended to be associated with low surface water temperatures at the pier.

Through August the water column was strongly stratified with the average difference in temperature and density between 4 and $23 \mathrm{~m}$ depth at the $25 \mathrm{~m}$ mooring equal to $6.3^{\circ} \mathrm{C}(\mathrm{SD}=0.7)$ and 3.2 sigma-t $(\mathrm{SD}=0.8)$, respectively (Fig. 3). On 3 September a strong wind event from the NE mixed the water column so that the differences in water temperature and density across the water column dropped sharply (Figs. 2 \& 3). Following this storm the average differences in temperature and density across the water column dropped to $0.5^{\circ} \mathrm{C}(\mathrm{SD}=$ 0.8 ) and 1.1 sigma-t ( $S D=1.1$ ), respectively.

The period of tidally driven internal waves is on the order of minutes. The interval between measurements of the physical variables ( $4 \mathrm{~min}$ ) was too long to allow tidally driven internal waves to be resolved. Tidally generated internal bores would be apparent in the physical data as rapid increases in density which last for several hours (Cairns 1967, Winant 1974, Pineda 1994). The density data collected every 4 min from the $23 \mathrm{~m}$ deep CTD on the $25 \mathrm{~m}$ mooring were plotted and the plots were inspected for rapid increases in density which might indicate the passage of internal bores. The number of rapid density increases per day (bore index) was cross-correlated with the other physical parameters.

The bore index was only significantly cross-correlated with the alongshore surface currents (at lags of 0 and $-1 \mathrm{~d} ; \mathrm{r}=-0.220$ and -0.256 , respectively) and the cross-shore surface currents (at lags of -3 and $-4 \mathrm{~d}$; $\mathrm{r}=$ -0.257 and -0.302 , respectively). Because for much of the study the density difference across the water column was $<1$ sigma-t, this index is probably not a sensitive indicator of the presence of internal bores.

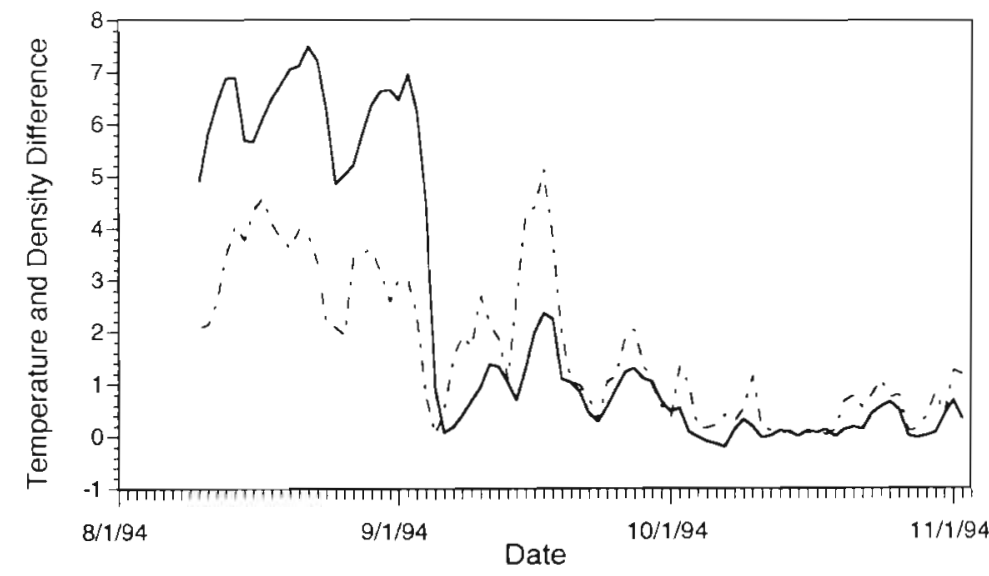

Fig. 3. Temperature (solid line) and density (sigma-t; dashed line) differences at the $25 \mathrm{~m}$ mooring between the surface ( $4 \mathrm{~m}$ depth) and near the bottom ( $23 \mathrm{~m}$ depth) during the study period 
Table 3. Callinectes sapidus, Penaeus spp., Uca spp. and Libinia spp. Summary of post-larval sampling. Samplers were set at the surface and near the bottom at the end of the Army Corps of Engineers' Field Research Facility pier at Duck, NC, and were deployed from 2 August to 3 November 1994

\begin{tabular}{|c|c|c|c|c|c|c|}
\hline \multirow[t]{3}{*}{ Species } & \multirow{3}{*}{$\begin{array}{c}\text { Dates present } \\
\text { (no. of days) }\end{array}$} & \multicolumn{4}{|c|}{ Sampler location } & \multirow{3}{*}{$\begin{array}{c}\text { Percent at } \\
\text { surface } \\
\text { Average (SD }\end{array}$} \\
\hline & & \multicolumn{2}{|c|}{ Surface } & \multicolumn{2}{|l|}{ Bottom } & \\
\hline & & Avg. no. $d^{-1}(S D)$ & Total & Avg. no. $d^{-1}$ (SD) & Total & \\
\hline Callinectes sapidus & 2 Aug - 2 Nov (93) & $94(427)$ & 8658 & $22(52)$ & 2063 & $60(32)$ \\
\hline Penaeus spp. & 3 Sep -2 Nov $(64)$ & $0(0)$ & 0 & $10(30)$ & 582 & $0(0)$ \\
\hline Uca spp. & 2 Aug -14 Oct $(77)$ & $3(10)$ & 229 & $2(5)$ & 168 & $35(40)$ \\
\hline Libinia spp. & 20 Aug - 2 Nov $(73)$ & $2(4)$ & 124 & $25(52)$ & 1851 & $11(23)$ \\
\hline
\end{tabular}

\section{Biological measurements}

A variety of post-larval crustaceans clung to and were caught on the collectors deployed from the FRF pier. The 4 most abundant post-larvae caught in order of abundance were Callinetes sapidus, Libinia spp., Penaeus spp., and Uca spp. (Table 3). This paper focuses on these organisms.

Callinectes sapidus megalopae were present in the samples throughout the study. Over 10000 individuals

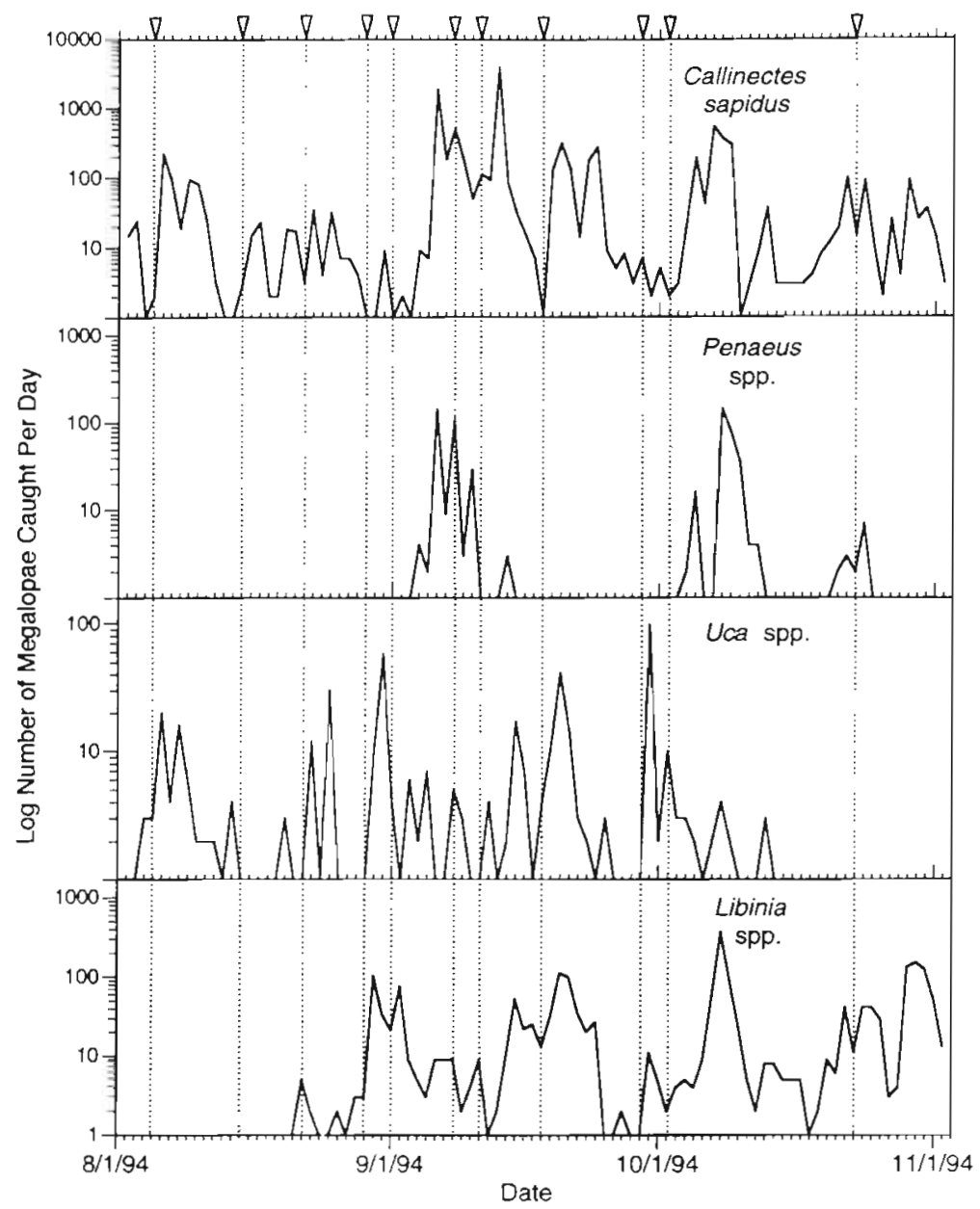

were sampled, most of which were caught on the surface trap (Table 3). Uca spp. megalopae were also present in the samples from the start of the study, but they dropped out of the samples after 14 October. A total of 397 individuals were caught, mostly on the bottom trap (Table 3). Libinia spp. megalopae first appeared in the samples on 20 August and continued to be caught to the end of the study. Most of the 1975 individuals were caught on the bottom trap (Table 3). Penaeus spp. postlarvae were the last to appear in the sampies. They were first collected on 3 September and continued through the remainder of the study. A total of 582 individuals were caught all on the bottom trap (Table 3). The daily catch of $C$. sapidus varied over 3 orders of magnitude while the daily abundance of UCa spp., Penaeus spp, and Libinia spp. varied over 2 orders of magnitude (Fig. 4).

In the following data presentation and analysis the number of individuals caught on the surface and bottom collectors have been combined.

The number of megalopae which were caught on the collectors could simply be a reflection of the amount of water which flowed past the end of the pier. The abundances of Uca spp. and Penaeus spp. were not significantly cross-correlated with the water velocity at any of the lags. The abundances of Callinectes sapidus and Libinia spp. megalopae were significantly but negatively correlated ( $\mathrm{r}$ equal to -0.279

Fig. 4. Callinectes sapidus, Penaeus spp., Uca spp. and Libinia spp. Time-series of the daily abundance (log scale) of post-larval crabs and shrimp sampled at the Army Corps of Engineers' Field Research Facility. Arrowheads at the top of the figure and vertical dotted lines indicate days when wind reversals suggest that upweiling fronts may have been relaxing toward shore 
Table 4. Callinectes sapidus, Penaeus spp., Uca spp. and Libinia spp. Post-larval abundances in relation to the lunar month and the fortnightly tidal cycle. Values are averages of the log-transformed abundance data (standard deviation and n are given in parentheses). $\chi^{2}$ and $p$ values are the results of a Kruskal-Wallis non-parametric analysis of variance applied to the log-transformed abundance data. The lunar month started on the day of the new moon while the tidal cycle started on the day of maximum tidal range during the new moon spring tides. The day of maximum tidal range during spring tides tended to occur about $2 \mathrm{~d}$ after the new or full moon. ns: not significant

\begin{tabular}{|c|c|c|c|c|c|c|}
\hline \multirow[t]{2}{*}{ Species } & \multirow[b]{2}{*}{ First ( $>26$ and $<4$ d) } & \multicolumn{2}{|c|}{ Phase of lunar month } & \multirow[b]{2}{*}{ Fourth (Days 20-26) } & \multicolumn{2}{|c|}{ Result of K-W test } \\
\hline & & Second (Days 4-11) & Third (Days 12-19) & & $\chi^{2}$ & $\mathrm{p}$ \\
\hline Callinectes sapidus & $1.77(0.78,23)$ & $1.00(0.91,24)$ & $1.33(0.64,24)$ & $0.69(0.57,22)$ & 4.88 & ns \\
\hline Penaeus spp. & $0.83(0.83,16)$ & $0.32(0.59,16)$ & $0.12(0.24 .16)$ & $0.00(0.00,16)$ & 12.80 & 0.005 \\
\hline Uca spp. & $0.47(0.38,20)$ & $0.22(0.34,24)$ & $0.48(0.58,18)$ & $0.49(0.63,15)$ & 6.46 & ns \\
\hline Libinia spp. & $1.02(0.61,16)$ & $0.96(0.52,16)$ & $0.83(0.72,20)$ & $1.06(0.73,21)$ & 5.15 & ns \\
\hline \multirow[t]{2}{*}{ Species } & \multicolumn{4}{|c|}{ Phase of tidal cycle } & \multicolumn{2}{|c|}{ Result of $\mathrm{K}-\mathrm{W}$ test } \\
\hline & First $(>26$ and $<4$ d) & Second (Days 4-11) & Third (Days 12-19) & Fourth (Days 20-26) & $\chi^{2}$ & $\mathrm{p}$ \\
\hline Callinectes sapidus & $1.54(0.78,21)$ & $1.36(0.89,24)$ & $0.80(0.77,24)$ & $1.07(0.73,24)$ & 12.51 & 0.006 \\
\hline Penaeus spp. & $0.12(0.22,14)$ & $0.73(0.74,16)$ & $0.17(0.60,16)$ & $0.00(0.00,18)$ & 19.47 & 0.0002 \\
\hline$U_{C a} \mathrm{spp}$ & $0.51(0.47,19)$ & $0.23(0.29,24)$ & $0.41(0.53,17)$ & $0.47(0.60,17)$ & 4.09 & ns \\
\hline Libinia spp. & $0.87(0.68,14)$ & $1.03(0.56,16)$ & $1.00(0.75,22)$ & $0.92(0.68,21)$ & 1.32 & ns \\
\hline
\end{tabular}

and -0.290 , respectively) with water velocity at 0 and $-1 \mathrm{~d}$ lag, respectively. Flow past the end of the pier either had no affect on catch or as flow increased catch decreased.

To investigate the possibility that the abundance of post-larvae varied with the lunar month or the fortnightly tidal cycle the log-transformed abundance data were sorted by lunar or tidal phase and averaged; these average values were tested with a KruskalWallis non-parametric analysis of variance (Table 4). For the phases of the tidal cycle the spring and neap tides were defined as the days on which the tidal range was maximal and minimal, respectively. Maximum spring tides tended to occur about 2 d after the new or full moon.

In the 4 quarters of the lunar month there were no significant differences in the abundance of the megalopae of $C$. sapidus, Uca spp., or Libinia spp. The abundance of post-larval Penaeus spp. was significantly different from random. They tended to be most abundant in the period around the first quarter moon (Table 4). When the month was divided by the phases of the fortnightly tidal cycle, no significant differences were found in the abundances of Uca spp. or Libinia spp. In contrast, the abundances of post-larval Penaeus spp. and the megalopae of $C$. sapidus were significantly different from random (Table 4). Post-larval Penaeus spp. tended to be most abundant during the second quarter of the tidal cycle. The results do not clearly indicate in which quarter blue crab megalopae were most abundant (Table 4)

To further investigate the potential fortnightly periodicity in the time-series of post-larval abundance, Fourier analyses were performed on each of the log- transformed post-larval abundance time-series. Strong peaks were found in the periodograms of both Callinectes sapidus and Penaeus spp. at a period of $15 \mathrm{~d}$ (Fig. 5). During the study, the average number of days between spring tides was $14.7 \mathrm{~d}$. No strong peaks were apparent in the Fourier analysis of the Uca spp. timeserjes and in the Libinia spp. time-series, a strong peak was found at a period of about $18 \mathrm{~d}$ (Fig. 5).

These results suggest that the abundance of Callinectes sapidus megalopae and Penaeus spp. post-larvae may vary with the fortnightly tidal cycle. However, the lack of any evidence for a roughly 14.7 d cycle in the abundance of Uca spp. or Libinia spp. suggests that their abundance did not vary with the fortnightly tidal cycle. To investigate this hypothesis cross-correlations were run between the maximum daily tidal range and the log-transformed daily abundance of megalopae and post-larvae (Fig. 5). This analysis found significant positive cross-correlations between the abundance of $C$. sapidus and Penaeus spp. and the maximum daily tidal range at lags of +2 to -4 or $-5 \mathrm{~d}$ lag (Fig. 5). In contrast, no significant cross-correlations were found between the abundance of Libinia spp. and the maximum daily tidal range. Weak, but still significant, negative cross-correlations were found at -4 to $-6 \mathrm{~d}$ lag between the tidal range and the abundance of Uca spp. Peaks in the catch of C. sapidus and Penaeus spp. tended to occur at or several days after the spring tides and there was a tendency for Uca spp. to be least abundant during the neap tides.

The abundance of megalopae was tested against the internal bore index. The bore index was not significantiy cross-correlated with the abundance of $C$. sapidus, Penaeus spp., or UCa spp. at any of the lags. 
Table 5. Callinectes sapidus, Penaeus spp., Uca spp. and Libinia spp. Cross-correlations between the daily abundance of postlarvae and the physical variables. The wind, nearshore current, temperature, and salinity data were collected near the end of the FRF pier Cross-shore and alongshore current data were collected at the $25 \mathrm{~m}$ moonng located $6 \mathrm{~km}$ offshore. Autoregressive integrated moving average models (ARIMA) were fitted to the time-series of physical data and to the log-transformed post-larval abundance data. The residuals between the ARIMA models and the raw data were calculated, and these residuals were used in the cross-correlation analysis. Values are days lag and cross-correlation coefficients at which significant $(p<0.05)$ cross-correlations were found. ns: not significant

\begin{tabular}{|c|c|c|c|c|c|c|c|c|c|}
\hline \multirow[t]{2}{*}{ Species } & \multicolumn{2}{|c|}{ Wind stress } & \multicolumn{2}{|c|}{ Cross-shore currents } & \multicolumn{2}{|c|}{ Alongshore currents } & \multirow{2}{*}{$\begin{array}{c}\text { Nearshore } \\
\text { current }\end{array}$} & \multirow[t]{2}{*}{ Temperature } & \multirow[t]{2}{*}{ Salinıty } \\
\hline & $\begin{array}{l}\text { Along- } \\
\text { shore }\end{array}$ & $\begin{array}{l}\text { Cross- } \\
\text { shore }\end{array}$ & $\begin{array}{c}\text { Surface, } \\
4 \mathrm{~m}\end{array}$ & $\begin{array}{c}\text { Bottom, } \\
18 \mathrm{~m}\end{array}$ & $\begin{array}{c}\text { Surface, } \\
4 \mathrm{~m}\end{array}$ & $\begin{array}{c}\text { Bottom } \\
18 \mathrm{~m}\end{array}$ & & & \\
\hline Callinectes sapidus & $s \mathrm{~ns}$ & ns & ns & ns & rns & ns & ns & ns & ns \\
\hline Penaeus spp. & ns & $-2:-0.290$ & $\begin{array}{r}0 .-0.366 \\
-1 .-0.309\end{array}$ & ns & ns & ns & ns & ns & ns \\
\hline Uca spp. & ns & ns & $-1:-0.239$ & $0: 0.373$ & ns & ns & ns & ns & $0:-0.255$ \\
\hline Libinia spp. & ns & ns & ns & ns & $0: 0.310$ & ns & ns & ns & ns \\
\hline
\end{tabular}

The index was significantly negatively cross-correlated with the abundance of Libinia spp. at lags of $-1,-2$, and $-4 \mathrm{~d}(\mathrm{r}=-0.261,-0.254$, and -0.295 , respectively $)$.

The residuals from the Callinectes sapidus ARIMA were not significantly cross-correlated with any of the physical variables at any of the lags (Table 5). The strong tidal signal in the $C$. sapidus timeseries and the lack of any significant cross-correlations with the other physical variable suggest that onshore transport of C. sapidus megalopae was dominated by some tidally driven mechanism.

In contrast, the residuals from the Penaeus spp. ARIMA were significantly and negatively cross-correlated at $-2 \mathrm{~d}$ lag with the cross-shore wind stress and at 0 and $-1 \mathrm{~d}$ lag with the cross-shore surface current (Table 5). These significant cross-correlations suggest that, in addition to some factor related to the fortnightly tidal cycle, the abundance of Penaeus spp. on the collectors was also higher during periods of onshore movement of the surface waters.

Similar results to those found for Penaeus spp. were found for Uca spp., i.e.

Fig. 5. Callinectes sapidus, Penaeus spp., Uca spp. and Libinia spp. Time-series analysis of the abundance of post-larval crabs and shrimp. On the left are the results of. Fourier analysis of the log-transformed daily abundance of postlarvae. On the right are the results of crosscorrelations between the maximum daily tidal range and the log-transformed daily abundance of post-larvae. The dashed lines indicate the $\mathrm{r}$ values needed to obtain a $\mathrm{p}<0.05$ significant negative cross-correlations were found at $-1 \mathrm{~d}$ lag between the residual and the cross-shore surface current and a significant positive cross-correlation
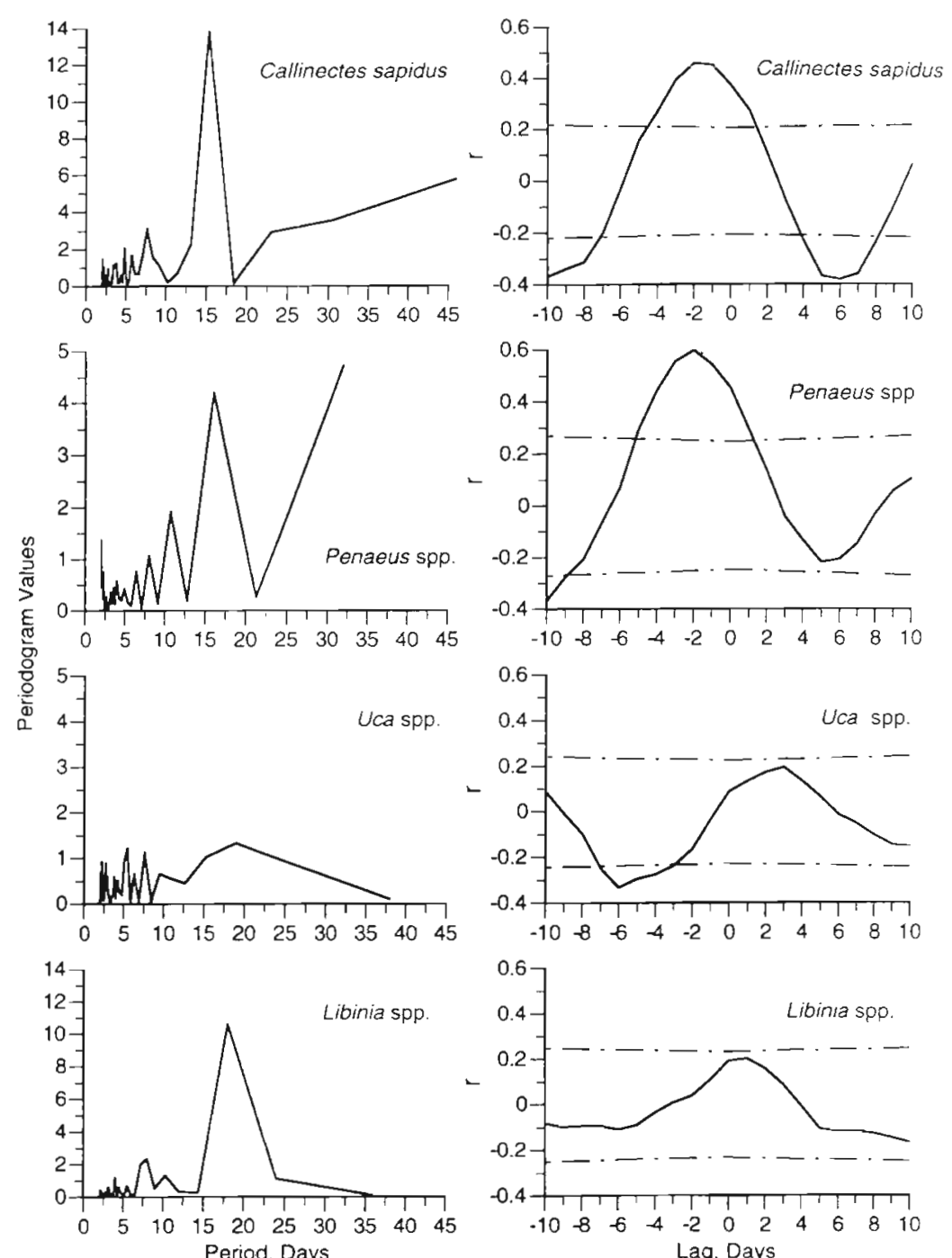
was found at 0 d lag with the cross-shore bottom current (Table 5). In addition, a significant negative crosscorrelation was found at 0 d lag with salinity at the end of the FRF pier (Table 5). This combination of significant cross-correlations suggests that, in addition to the effect of the tides, larger catches of Uca spp. were associated with onshore movement of surface waters.

The residuals from the Libinia spp. ARIMA were also significantly cross-correlated with some of the physical variables. A significant positive cross-correlation at $0 \mathrm{~d}$ lag was found between the residuals from the ARIMA of megalopal abundance and the alongshore surface currents (Table 5). Additionally, a significant negative cross-correlation was found at -1 d lag with the nearshore current flow at the end of the FRF pier (Table 5). These significant cross-correlations are consistent with higher catches of Libinia spp. occurring during periods of northward flowing currents and upwelling.

Recent evidence suggests that larval invertebrates can be transported shoreward at the end of an upwelling event as the upwelling front relaxes toward shore (Shanks 1998). At the Duck sample site upwelling fronts have been observed to propagate past the end of the FRF pier and into the surf zone (Porter et al. 1998). To identify days when an upwelling front might have been propagating shoreward, the wind record was inspected for periods when the winds reversed from upwelling favorable (e.g. from the west through to the south) to downwelling favorable (e.g. from the north through to the east). The arrows at the top of Fig. 4 indicate the days when upwelling fronts may have been propagating onshore. We expect the catch to be significantly higher on days when upwelling fronts came ashore than on days when they did not. To test this hypothesis a $t$-test was run comparing megalopal abundances on days when an upwelling front was predicted to have been propagating ashore to the abundances on all other days. No signifjcant $t$ values ( 1 -tailed test, $p>0.05$ ) were found for any of the organisms investigated. This was true whether the $t$-test was run on the log-transformed abundances or on the ARIMA residuals.

\section{DISCUSSION}

Currents over the Mid-Atlantic Bight are dominated by the winds (Wright 1995). The dominant winds during the study were from the NE and SW (Fig. 2). Winds from the NE caused downwelling events with southward-flowing alongshore currents, shoreward-flowing surface currents, and bottom currents flowing offshore. During downwelling the coastal waters tended to be warmer and have lower salinity. Winds from the SW caused upwelling with northward-flowing alongshore currents, seaward-flowing surface currents, and bottom currents flowing onshore. At these times, the coastal waters tended to be cooler and have higher salinity. The winds caused the coastal currents to cycle between downwelling and upwelling.

The Chesapeake Bay injects a tremendous amount of low salinity water into the Mid-Atlantic Bight (Boicourt 1973). During NE winds the onshore surface flow pushed this plume of low salinity water against the shore and directed the plume southward along the coast (S. E. Rennie, J. L. Largier \& S. J. Lentz unpubl data). In this study, the velocity of the plume ranged from 30 to $70 \mathrm{~cm} \mathrm{~s}^{-1}$ and was driven by buoyancy and the winds. The presence of the plume is apparent in the physical data as periods of very low salinity $(<30)$ and high alongshore flows at the FRF pier. During upwelling, the offshore movement of the surface waters caused the plume to thin, spread seaward, and detach from the coast.

The collectors at the FRF pier on average caught $>90$ blue crab megalopae $\mathrm{d}^{-1}$ with peak catches in the thousands (Table 3, Fig. 4). The results of the Fourier analysis and cross-correlations suggest that the abundance of blue crab megalopae at this site outside of an estuary tended to peak around the spring tides. Using similar sampling techniques for post-larvae a number of investigators (van Montifrans et al. 1990, 1995, Olmi 1991, Rabalais et al. 1995, van Montfrans et al. 1995) have looked at variations in the daily abundance of Callinetes sapidus megalopae within estuaries. In most of these previous studies researchers also found that the daily abundance of blue crab megalopae varied with the phase of the moon, and, hence, the tides (Goodrich et al. 1989, van Montifrans et al. 1990, Boyland \& Wenner 1993, Jones \& Epifanio 1995, Mense et al. 1995, Metcalf et al. 1995, Olmi 1995, Wrona et al. 1995). Over all, these previous studies and the results from this study are in agreement.

A number of studies along the Atlantic coast of North America have attempted to relate the daily abundance of blue crab megalopae to the coastal winds (Goodrich et al. 1989, Boyland and Wenner 1993, Blanton et al. 1995, Mense et al. 1995, Olmi 1995). In general, these studies suggest that samples collected within an estuary tend to vary with wind direction, with peak catches tending to occur when the winds are from the northeast. In the work reported here, no significant relationships were found between wind direction and the abundance of blue crab megalopae.

What might account for the similarities and differences between the previous studies which sampled within estuaries and the study reported here which took place on the open coast? The abundance of megalopae at a site within an estuary will be depend on at 
least 2 factors, which are: (1) the transport of larvae to the coast and (2) the ingress of the larvae into the estuary. The abundance of megalopae at a coastal site is only dependent on the shoreward transport of larvae. Perhaps the consistent similar features of the timeseries collected within estuaries and the one collected on the open coast are due to the transport mechanism across the shelf. Consistent amongst all of the data sets is a variation in blue crab megalopal abundance with either the phase of the moon or tides. These results suggest that onshore transport is due to a tidally driven phenomena. What is apparent in most of the estuarine time-series, but not in the coastal samples, is a windrelated variation in the megalopal abundance. The work of Goodrich et al. (1989) suggests that ingress into the Chesapeake Bay is, at least in part, dependent on wind-driven coastal set up forcing coastal waters into the estuary. Perhaps the significant effect of the winds seen in the time-series collected within estuaries is an indication of the importance of wind-driven flow on the ingress of megalopae into an estuary.

The shoreward migration of blue crab megalopae appears to be driven by tides and we know that the blue crab megalopae inhabit the neuston (Smyth 1980, Johnson 1985). Given this combination of facts, there are 2 possible mechanisms which might explain their onshore migration; they may be transported shoreward (1) in convergences over tidally generated internal waves (Shanks 1988), or (2) in convergences generated during the relaxation from an upwelling event generated by an internal tidal bore (Pineda 1994).

Tidally driven internal waves are a characteristic feature of many continental shelves (Arthur 1954, Curtin \& Mooers 1975, Gargett 1976, Chereskin 1983, Sawyer 1983, Kingsford \& Choat 1986). Using satellite images researchers have observed the surface manifestations of internal waves in the Mid-Atlantic Bight. Sawyer (1983) studied 3 yr of Landsat images (1972-1974) of the Mid-Atlantic Bight collected during the months of May through September. In the Landsat images internal waves were apparent throughout the Mid-Atlantic Bight, including directly offshore of the Duck sample site. From the satellite images Sawyer (1983) and Apel et al. (1975) determined that internal wave packets can last for several days, during which time they were found to traverse even the broad continental shelf of the Mid-Atlantic Bight. During the CoOP study, sets of surface slicks characteristic of internal wave convergences were observed in the coastal waters adjacent to the FRF pier (pers. obs.). In the Mid-Atlantic Bight between Cape Hatteras and the Delaware Bay, tidally generated internal waves are present and common.

In the waters off Beaufort, North Carolina, Shanks (1988) tested the hypothesis that internal waves could cause the shoreward transport of larval invertebrates and fish. This study demonstrated that internal waves transport a variety of larvae, including blue crab megalopae and post-larval Penaeus spp., shoreward. The magnitudes of the internal tides, internal tidal bores, and tidally generated internal waves all vary with the fortnightly tidal cycle (Cairns 1967, 1968, Pineda 1991); the larger the tidal range, the larger the internal waves generated. This fortnightly variations in the size of the internal waves may lead to a fortnightly variation in settlement. For example, Shanks \& Wright (1987) demonstrated that the cyprids of some types of intertidal barnacles are transported shoreward in the convergence over internal waves. Pineda (1991) and Shanks (1986) found that peaks in barnacle settlement tended to occur between the neap and spring tides when large internal bores and the accompanying internal waves (Winant 1974) impinged on the coast. These studies suggest that variation in barnacle settlement was driven by variations in the strength of an onshore transport mechanism: tidally driven internal waves or internal bores. The often observed fortnightly variations in blue crab abundance may be due to the fact that they can be transported shoreward in the convergences over tidally driven internal waves (Shanks 1988) and the transporting capacity of internal waves may vary over the spring to neap tidal cycle.

Peak catches of Penaeus spp. post-larvae tended to occur at or slightly after the new moon (Table 4). No or few post-larvae were caught around the time of the full moon (Table 4). A number of studies have arrived at a similar conclusion (Williams \& Deubler 1968, Allen et al. 1980, Olmi 1986, Brady 1994, DeLancey et al. 1994). The cross-correlation analysis also suggested that the abundance of Penaeus spp. tended to be larger 1 to $2 \mathrm{~d}$ after periods of onshore winds and currents. Williams \& Deubler (1968) did not find a statistically significant relationship between catch of Penaeus spp. larvae and wind direction at $0 \mathrm{~d}$ lag, but they did not test longer lags.

Penaeus spp. post-larvae make a diel vertical migration from within the water column during the daylight hours to the surface waters at night (Temple \& Fischer 1965, Jones et al. 1970). Like the larvae of the western Australian rock lobster (Phillips et al. 1978), Penaeus spp. post-larvae may migrate into the surface waters and neuston during dark moonless nights. When in the neuston, the post-larvae should be transported downwind by wind-driven surface currents such as Langmuir circulation (Leibovich 1983). Like blue crab megalopae, Penaeus spp. post-larvae, when in the neuston, should become concentrated in convergence zones and if the convergence zone moves shoreward then so should the post-larvae within the convergence zone. Shanks (1988) found that Penaeus spp. post-lar- 
vae were concentrated in the convergence zone over tidally forced internal waves, and as these internal waves propagated shoreward the post-larvae were transported shoreward in the internal wave convergences. Further, Penaeus spp. post-larvae may be transported shoreward in the moving convergence zone associated with the relaxation events following wind-driven or tidally driven upwelling events (Roughgarden et al. 1991, Pineda 1994, Shanks 1998).

The observed pattern of abundance of shrimp postlarvae at the FRF pier may be due to a combination of onshore transport mechanisms modified by vertical migration. If the shoreward transport of post-larvae occurs via shoreward propagating surface convergences, then transport will only occur when the larvae are at the surface. Around the time of the dark of the new moon, larvae which migrate to the ocean's surface may be transported shoreward in convergences. In contrast, around the time of the full moon shrimp postlarvae may avoid the more illuminated surface waters, in which case they would not be transported shoreward.

Uca spp. post-larvae must settle in an estuarine environment. Their larvae are dispersed over the continental shelf out to about $60 \mathrm{~km}$ from shore (Smyth 1980) and they tend to be found during the day below the pcynocline or at least deep in the water column (Johnson 1985). Within Chesapeake Bay, fiddler crab megalopae make a diel vertical migration (Maris 1986). There are, however, apparently no observations of the vertical migratory behavior of Uca spp. larvae over the shelf.

The daily abundance of Uca spp. has been measured in several estuaries along the east coast of North America. Boylan \& Wenner (1993) found that abundance peaks occurred around neap tides, while Mense et al. (1995) and Wrona et al. (1995) found peaks occurring around the times of the new and full moons. Jones \& Epifanio (1995) found no relationship between catch and phase of the moon. None of these studies found relationships between the abundance of Uca spp. megalopae and the wind. The differences between these studies may be due to real differences between locations or may simply be due to the variety of statistics applied to the data sets.

The small correlation coefficient between the abundance of Uca spp. and the tidal range suggests a weak tidal effect, with peak catches occurring around the spring tides. The effect of the wind appears to be stronger, with peak catches tending to occur during periods of wind-driven onshore surface flow (Fig. 4, Table 5).

Libinia spp. megalopae tend to be found below the pcynocline or in the lower half of the water column (Williams 1984, Johnson 1985). The Fourier analysis suggested there was an $18 \mathrm{~d}$ cycle to settlement, there were no significant cross-correlation with the tides, and peak catches tended to occur when surface currents were flowing to the north. Comparing the wind stress (Fig. 2) with settlement (Fig. 4) one can see that peaks in settlement of Libinia spp. tended to occur during periods when the wind stress was to the north and, to a lesser extent, offshore, e.g upwelling winds. Peaks in settlement and wind events were on average $19 \mathrm{~d}$ apart, close to the $18 \mathrm{~d}$ cycle found in the Fourier analysis. The shoreward transport of Libinia spp. megalopae appears to have been primarily due to upwelling.

Callinectes sapidus, Uca spp., and Penaeus spp. all recruit into estuaries. The pattern of abundance of these organisms suggests that their onshore transport was due to a tidally driven mechanism and/or onshore wind-driven surface flow. The available data on the pattern of settlement of intertidal crabs (Shanks 1983, 1985, 1988) and barnacles (Hawkins \& Hartnoll 1982, Shanks 1986, Shanks \& Wright 1987, Pineda 1991) suggest that these organisms are also transported shoreward by the tides or winds. In contrast, post-larvae of Libinia spp., which inhabits the shallow subtidal benthos over the continental shelf or the higher salinity outer reaches of estuaries (Williams 1984), were apparently transported shoreward in near-bottom waters during upwelling conditions. Perhaps organisms which must settle in the intertidal or are estuarine dependent have evolved behaviors which exploit onshore transport which occurs at the surface, while organisms which settle more broadly over the shelf have evolved behaviors which exploit transport by bottom currents.

Acknowledgements. Field assistance was provided by $M$ Amend, K. Johnson, T. Rippietoe, M. Hearn and by the Army Corps of Engineers' Field Research Facility. The physical oceanographic data were provided by Dr S. Lentz and the Army Corps of Engineers' Field Research Facility. Drs S. Lentz and J. Largier and 3 anonymous reviewers provided valuable advice during the writing of this manuscript. This research was supported by the National Science Foundation, Coastal Ocean Processes Grants OCE-9123514 and OCE9633071.

\section{LITERATURE CITED}

Alessi CA, Lentz SJ, Austin J (1996) Coastal ocean processes inner-shelf study: coastal and moored physical oceanographic measurements. Woods Hole Oceanogr lnst, Tech Rep. WHOI-96-06

Allen DM, Hudson J'H, Costello TJ (1980) Postlarval shrimp (Penaeus) in the Florida Keys: species, size and seasonal abundance. Bull Mar Sci 30:21-34

Apel W, Byrne HM, Proni JR, Charnell RL (1975) Observations of oceanic internal and surface waves from the Earth Resources Technology Satellite. J Geophys Res 90: 865-881 
Arthur RS (1954) Oscillations in sea temperature at Scripps and Oceanside Piers. Deep Sea Res 2:129-143

Birkemeier WA, DeWall AE, Gorbics CS, Miller HC (1981) A Users Guide to CERC's Field Research Facility. U.S. Army Corps of Engineers, Waterways Experimental Station, Vicksburg, MS, Rep No. CERC MR 81-7

Blanton J, Wenner E, Werner F, Knott D (1995) Effects of wind-generated coastal currents on the transport of blue crab megalopae on a shallow continental shelf. Bull Mar Sci 57:739-752

Boehlert GW, Mundy BC (1988) Roles of behavioral and physical factors in larval and juvenile fish recruitment to estuarine nursery areas. In: Weinstein MP (ed) Larval fish and shellfish transport through inlets. American Fisheries Society, Bethesda, MD, p 51-67

Boicourt WC (1973) The circulation on the continental shelf from Chesapeake Bay to Cape Hatteras. PhD thesis. The John Hopkins University, Baltimore, MD

Boyland. JM, Wenner EL (1993) Settlement of brachyuran megalopae in a South Carolina, USA, estuary. Mar Ecol Prog Ser 97:237-246

Brady MK (1994) The use of ingress data to suggest possible cross-shelf transport mechanisms for postlarvae of the brown shrimp, Penaeus aztecus, into the Charleston estuary, Charleston, S.C. Masters thesis, University of Charleston. $\mathrm{SC}$

Cairns JL (1967) Asymmetry of internal tidal waves in shallow coastal waters. J Geophys Res 72:3563--3565

Cairns JL (1968) Thermocline strength fluctuations in coastal waters. J Geophys Res 73:2591-2595

Chereskin TK (1983) Generation of internal waves in Massachusetts Bay. J Geophys Res 88:2649-2661

Cook HL (1966) A generic key to the protozoean, mysis, and postlarval stages of the littoral Penaeidae of the northwestern Gulf of Mexico. Fish Bull US 65:437-447

Costlow JDJ, Bookhout CG (1959) the larval development of Callinectes sapidus Rathbun reared in the laboratory. Biol Bull. (Woods Hole) 116:373-396

Curtin TB, Mooers CNK (1975) Observation and interpretation of a high-frequency internal wave packet and surface slick pattern. J Geophys Res 80:882-894

DeLancey LB, Jenkins JE, Whitaker JD (1994) Results of longterm, seasonal sampling for Penaeus postlarvae at Breach Inlet, South Carolina. Fish Bull US 92:633-640

Dudley DL, Judy MH (1971) Occurrence of larval, juvenile, and mature crabs in the vicinity of Beaufort Inlet, North Carolina. NOAA Tech Rep NMFS SSRF-637

Dunstan FDJ (1993) Time series analysis. In: Fry JC (ed) Bılogical data analysis: a practical approach. 1st edn. Oxford University Press, New York, p 243-310

Gargett AE (1976) Generation of internal waves in the Strait of Georgia, British Columbia. Deep Sea Res 23:17-32

Goodrich DM, van Montfrans J, Orth RJ (1989) Blue crab megalopal influx to Chesapeake Bay: evidence for a winddriven mechanism. Estuar Coast Shelf Sci 29:247-260

Hawkins SJ, Hartnoll RG (1982) Settlement patterns of Semibalanus balanoides (L.) in the Isle of Man (1977-1981). J Exp Mar Biol Ecol 62:119-126

Hyman OW (1920) The development of Gelasimus after hatching. J Morphol 33:485-501

Jassby AD, Powell TM (1990) Detecting changes in ecological time series. Ecology 71:2044-2052

Johns DM, Lang WH (1977) Larval development of the spider crab, Libinia emarginata (Majidae). Fish Bull US 75 : $831-841$

Johnson DF (1985) The distribution of brachyuran crustacean megalopae in the waters of the York River, lower Chesa- peake Bay and adjacent shelf: implications for recruitment. Estuar Coast Shelf Scl 20:693-705

Jones AC, Dimitriou DE, Ewald JJ, Tweedy JH (1970) Distribution of early developmental stages of Pink shrimp. Penaeus duorarum, in Florida waters. Bull Mar Scı 20 635-661

Jones MB, Eplfanio CE (1.995) Settlement of brachyuran megalopae in Delaware Bay: an analysis of time series data. Mar Ecol Prog Ser 125:67-76

Kennedy JS (1961) A turning point in the study of insect migration. Nature 189:785-791

Kingsford MJ, Choat JH (1986) The influence of surface slicks on the distribution and onshore movement of small fish. Mar Biol 91:161-171

Leibovich S (1983) The form and dynamics of Langmuir circulations. Annu Rev Fluid Mech 15:391-427

Maris RC (1986) Patterns of diurnal vertical distribution and dispersal-recruitment mechanisms of decapod crustacean larvae and postlarvae in the Chesapeake Bay, Virginia and adjacent offshore waters. Masters thesis, Old Dominion University, VA

Mense DJ, Posey MH, West T, Kincheloe T (1995) Settlement of brachyuran postlarvae along the North Carolina coast. Bull Mar Sci 57:793-806

Metcalf KS, van Montfrans J, Lipcius RN, Orth RJ (1995) Setthement indices for blue crab megalopae in the York River, Virginia: temporal relationships and statistical efficiency. Bull Mar Sci 57:781-792

Morgan SG, Zimmer-Faust RK, Heck KL Jr, Coen LD (1996) Population regulation of blue crabs Callinectes sapidus in the northern Gulf of Mexico: postlarval supply. Mar Ecol Prog Ser 133:73-88

Olmi EJ III (1986) Factors affecting the abundance of penaeid shrimps in macroplankton samples from open and impounded brackish marsh systems in South Carolına. Masters thesis, College of Charleston, SC

Olmi EJ IIl (1991) Immigration of blue crab megalopae in the York River, Virginia: patterns and processes. J Shellish Res 10:305

Olmi EJ IIl (1995) Ingress of blue crab megalopae in the York River, Virginia, 1987-1989. Bull Mar Sci 57:753-780

Pedlosky J (1987) Geophysical fluid dynamics. Spnnger-Verlag, New York

Phillips BF, Rimmer DW, Reid DD (1978) Ecological investigations of the late stage phyllosoma and puerulus larvae of the western rock lobster Panulirus longipes cygnus. Mar Biol 54:347-357

Pineda J (1991) Predictable upwelling and the shoreward transport of planktonic larvae by internal tidal bores Science 253:548-551

Pineda $J$ (1994) Internal tidal bores in the nearshore: warmwater fronts, seaward gravity currents and the onshore transport of neustonic larvae. J Mar Res 52:427-458

Porter DL, Sikora TD, Wiseup MD (1998) Air-sea interaction associated with the relaxation of an upwelling event off the coast of Duck, North Carolina. EOS 79:172

Rabalais NN, Burditt FRJ, Coen LD, Cole BE, Eleuterius C, Heck KL Jr, McTigue TA, Morgan SG, Perry HM, Truesdale FM, Zimmer-Faust RK, Zimmerman RJ (1995) Settlement of Callinectes sapidus megalopae on artificial collectors in four Gulf of Mexico estuaries. Bull Mar Sci. 57. $855-876$

Roughgarden J, Pennington JT, Stoner D, Alexander S, Miller $K$ (1991) Collisions of upwelling fronts with the intertidal zone: the cause of recruitment pulses in barnacle populations of central California. Acta Oecologia 12:35-51

Sandifer PA, Van Engel WA (1971) Larval development of the 
spider crab, Libinia dubial H. Milne Edwards (Brachyura, Majidae, Pisinae), reared in laboratory culture. Chesapeake Sci 12:18-25

Sawyer C (1983) A satellite study of ocean internal waves. NOAA Tech Memo ERL-PMEL-46

Shanks A.L (1983) Surface slicks associated with tidally forced internal waves may transport pelagic larvae of benthic invertebrates and fishes shoreward. Mar Ecol Prog Ser 13:311-315

Shanks AL (1985) Mechanisms of cross-shelf larval migration. In: Herrnkind WF, Thistle AB (eds) Signposts in the sea. Department of Biological Science, Florida State University, Tallahassee, p 15-28

Shanks AL (1986) Tidal periodicity in the daily settlement of intertidal barnacle larvae and an hypothesized mechanism for the cross-shelf transport of cyprids. Biol Bull (Woods Hole) 170:429-440

Shanks AL (1988) Further support fo the hypothesis that internal waves can transport larvae of invertebrates and fish onshore. Fish Bull US 86:703-714

Shanks AL (1995) Mechanisms of cross-shelf dispersal of larval invertebrates and fish. In: McEdward LR (ed) Ecology of marine invertebrate larvae. CRC Press Inc, Boca Raton, FL, p 323-368

Shanks AL (1998) Evidence for the shoreward transport of larval invertebrates by an upwelling front propagating toward shore. EOS 79:172

Shanks AL, Wright WG (1987) Internal wave-mediated shoreward transport of cyprids, megalopae, and gammarids and correlated longshore differences in the settling rate of intertidal barnacles. J Exp Mar Biol Ecol 114:1-13

Smyth PO (1980) Callinectes (Decapoda: Portunidae) larvae in the Middle Atlantic Bight, 1975-77. Fish Bull US 78:251-265

Editorial responsibility: Joseph Pawlik (Contributing Editor). Wilmington, North Carolina, USA
Temple RF, Fischer CC (1965) Vertical distribution of the planktonic stages of penaeid shrimp. Publ Inst Mar Sci, Texas 10:59-67

Thorrold SR, Shenker JM, Maddox ED, Mojica R, Wishinski E (1994) Larval supply of shorefishes to nursery habitats around Lee Stocking Island, Bahamas. II. Lunar and oceanographic influences. Mar Biol 118:567-578

van Montfrans J, Epifanio CE, Knott DM, Lipcius RN, Mense DJ, Metcalf KS, Olmi EJ III, Orth RJ, Posey MH, Wenner E L. West TL (1995) Settlement of blue crab postlarvae in western North Atlantic estuaries. Bull Mar Sci 57:834-854

van Montifrans J, Peery CA, Orth RJ (1990) Daily, monthly and annual settlement patterns by Callinectes sapidus and Neopanope sayi megalopae on artificial collectors deployed in the York River, Virginia. Bull Mar Sci 46: $214-229$

Williams AB (1984) Shrimps, lobsters, and crabs of the Atlantic coast of the eastern United States, Maine to Florida. Smithsonian Institution Press, Washington, DC

Williams $A B$, Deubler EE (1968) A ten-year study of meroplankton in North Carolina estuaries: assessment of environmental factors and sampling success among bothid flounders and penaeid shrimp. Chesapeake Sci 9:27-41

Winant CD (1974) Internal surges in coastal waters. J Geophys Res 79:4523-4526

Wing SR, Largier JL, Botsford LW, Quinn JF (1995) Settlement and transport of benthic invertebrates in an intermittent upwelling region. Limnol Oceanogr 40:316-329

Wright LD (1995) Morphodynamics of inner continental shelves. CRC Press, Boca Raton

Wrona AB, Wlegert RG, Bishop TD (1995) Initial report of settlement patterns of brachyuran megalopae at Sapelo Island, Georgia, U.S.A. Bull Mar Sci 57:807-820

Submitted: February 26, 1998; Accepted: April 21, 1998 Proofs received from author(s): June 9, 1998 